\title{
The Risk Factors and Chemical Composition of Encrustation of Ureteral Double J Stents in Patients with Urolithiasis
}

\author{
IOAN SCARNECIU1,2, OVIDIU GABRIEL BRATU3,4,5*, CALIN PAVEL COBELSCHI², CARMEN DANIELA NECULOIU², \\ CAMELIA CORNELIA SCARNECIU1,2, SORIN LUPU ${ }^{1}$, ADRIAN BRINZA2, DRAGOS MARCU ${ }^{3,4}$, BOGDAN SOCEA $^{4,6}$, LAURIAN MAXIM ${ }^{1,2}$ \\ IUniversity of Medicine and Pharmacy Transilvania, 56 $6^{\text {th }}$ Nicolae Balcescu Str., 500019, Brasov, Romania \\ ${ }^{2}$ Clinical Emergency County Hospital, 25-27th Bucuresti Road, 500326, Brasov, Romania \\ ${ }^{3}$ Carol Davila University Emergency Central Military Hospital, 88 \\ ${ }^{4}$ Carol Davila University of Medicine and Pharmacy, $8^{\text {th }}$ Eroii Sanitari Str., 050474, Bucharest, Romania \\ ${ }^{5}$ Academy of Romanian Scientists, $54^{\text {th }}$ Splaiul Independentei, 030167, Bucharest, Romania \\ ${ }^{6}$ Department of Surgery, Sf. Pantelimon Emergency Universitary Hospital, 340-342 ${ }^{\text {nd }}$ Pantelimon Road, 021623, Bucharest, Romania
}

\begin{abstract}
Ureteral stenting has become one of the most common endoscopic procedure in endourology. Its main purpose is to preserve urinary drainage if this is compromised and maintain a good renal function. Even if there were made significant improvements in the last 50 years, ureteral stenting is not without morbidity. The common ureteral stents cannot have a good long-term efficiency and at some points, it will be blocked by the encrustation and incrustation; as result, the urinary drainage will have to suffer. A total of 134 ureteral stents in 83 patients suffering from reno/ureteral lithiasis were examined. We investigated the risk factors of encrustation and analyzed the chemical compounds of it. A total of 57 stents were found encrusted. The main risk factor was represented by the indwelling time. The rate of encrustation was $18.33 \%$ in the first 5 weeks, $56 \%$ between week 6 and 12, 75\% thereafter. Stents with a smaller caliber ( $4.8 \mathrm{CH})$ tend to be more encrusted than those with a bigger one $(6 \mathrm{CH})$. The Fourier Transform Infrared Spectroscopy has found that the main chemical compound of encrustation is represented by calcium oxalate.
\end{abstract}

Key words: encrustation, ureteral double J stent, urolithiasis.

For the first time Finney and Hepperlen used modern double JJ ureteral stent in 1978 [1], however, the first ureteral stent placed trough cystoscopy was performed by Zimskind and Associates in 1967 [2]. These two events marked a new era in the management of urolithiasis, acute obstructive renal failure and renal colic, especially in cases where extracorporeal wave lithotripsy or pharmaceutical management were ineffective $[3,4]$. Thereby, the double J] has become one of the most used endoscopic procedures [5]. These particular cases were at risk of developing chronic renal failure, due to permanent obstruction and underlying hydronephrosis $[6,7]$. Throughout the time, the ureteral stent have suffered significant changes regarding its design and material, however the ideal ureteral stent hasn't been developed yet [3].

When the stents contacts urine, its biomaterial enters in a reaction with the organic materials, uropathogens and urinary salts [8]. The primordial effect on encrustation it's caused by urinary tract infections that form an organic lair on the stents; the reports show that most of the stents are colonized with bacteria (68\%-90\%) even this the bacteriuria is present in $27-30 \%$ of cases $[9,10]$.

Our main goal of this study was to evaluate the risk factors of encrustation within the patients with renoureteral lithiasis. The second goal is to evaluate the chemical composition of the encrustation.

\section{Experimental part}

Materials and methods

A total of 134 ureteral stents in 83 patients known with urolithiasis were investigated in our center between September 2017 and August 2018. Informed consent was obtained from all the patients. The stents were extracted with the following types of anesthesia: local, sedoanalgesia or general anesthesia. After the extraction of the Jj stents, those were examined for the grade of encrustation and the modification of the color. Also, it was examined the situs of encrustation (proximal/distal volute or body of the JJ stent). In case of presence of encrustation, those were sent to the lab for mineralogical exam (FT-IR); the lab results were divided in 2 big categories: singlecompound and mixt stones. The encrustations were divided in two groups (sever encrustation and moderate encrustation).

The level of resistance that was required to extract the stent was divided in 3 grades. Easy to extract- there were no resistance in the extraction. Moderate resistance - the stent that required more time to be extracted cistoscopically. Irremovable -the stents that required other interventions then cistoscopical extraction. The modification of the color was divided in two groups: stents with minimal modification of the color on at least $1 / 2$ of the distance; and stents with essential modification of the color on at least $1 / 2$ of the distance.

\section{Statistical analysis}

The statistical analysis was accomplished with the help of Epilnfo 7.2.2.6 created by CDC USA.

\section{Results and Discussion}

A total of 134 ureteral J J stents were extracted from 83 patients. All the stents were placed cistoscopically for the ureteral/renal lithiasis. Of the total 134 stents: 20 patients had 2 replacement, 9 patients had 3 or more replacement. All the ureteral Jj stent was made of polyurethane. Table 1 shows characteristics of patients and ureteral stents. From 134 of stents, the encrustation was observed in 57 of cases (42.5\%). Of these, $32(23.36 \%)$ had more than one situs of encrustation. Table 2 shows location and grade of encrustation in the ureteral stent.

A smaller caliber stent $(4.8 \mathrm{CH})$ was more frequent encrusted in comparison with a larger one $(6 \mathrm{CH})$ being significantly correlated ( $p=0.031$ ) (fig. 1$)$. 
Table 1

CHARACTERISTICSOF PATIENTSANDURETERAL STENTS

\begin{tabular}{|c|c|}
\hline Variables & Number ( $\%$ or range) \\
\hline No. of stents & 134 \\
\hline No. of patients & 83 \\
\hline Median age & $53.6(19-78)$ \\
\hline \multicolumn{2}{|l|}{ Sex } \\
\hline Male & $47(56.62 \%)$ \\
\hline Female & $36(43.38 \%)$ \\
\hline \multicolumn{2}{|l|}{ Side } \\
\hline Left & $72(53.73 \%)$ \\
\hline Right & $62(46.27 \%)$ \\
\hline Median indwelling time (d) & $49.7(4-278)$ \\
\hline \multicolumn{2}{|l|}{ Stent caliber } \\
\hline $4.8 \mathrm{Ch}$ & $18(13.43 \%)$ \\
\hline $6 \mathrm{Ch}$ & $116(86.57 \%)$ \\
\hline Stent length & $26 \mathrm{~cm}$ \\
\hline
\end{tabular}

Table 2

LOCATION AND GRADE OF ENCRUSTATION IN THE URETERAL

\begin{tabular}{|l|l|l|l|}
\hline Encrustation & Proximal & Body & Distal \\
\hline Encrusted & 31 & 13 & 23 \\
\hline Moderate encrustation & 26 & 10 & 19 \\
\hline Sever encrustation & 5 & 3 & 4 \\
\hline
\end{tabular}

Encrustation in \% $\mathrm{p}=0.031$

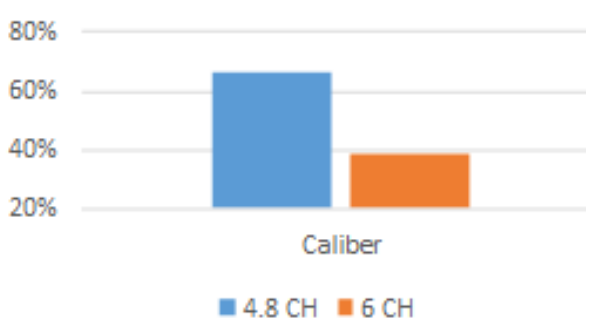

Fig. 1. The correlation between the stent calıber and encrustation

Of 134 ureteral stents 20 (14.92\%) JJ stents needed more time for extraction; and 4(2.98\%) of them were irremovable and needed other urological procedures for extraction.

The indwelling time is a primordial risk factor in the encrustation. Stents with a bigger indwelling time had a greater chance to be encrusted with significant correlation between them ( $p=0.000000669)$. The correlation was shown in Figure 2. At the same time stents with a bigger indwelling time have greater rate of modification of color than those extracted in the first 5 weeks $(p=0.003293)$, correlation that is presented in Figure 3.
Encrustation in \% $p=0.000000669$

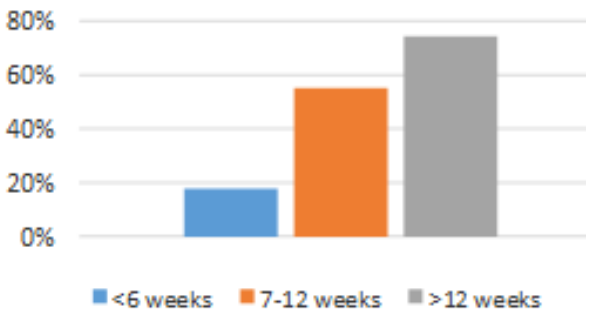

Fig. 2. The correlation between the indwelling time and encrustation

\section{Color modification \%} $p=0.003293$

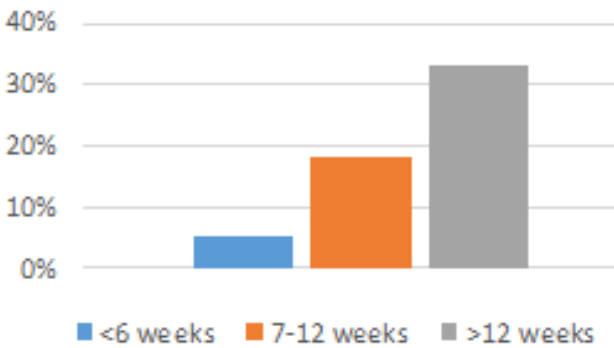

Fig. 3. The correlation of indwelling time and encrustation

Even though there were no significant correlation between the resistance at the extraction of the stent and the indwelling time, the trend seems to be: a greater indwelling time may be associated with a greater effort that will be needed to extract the stent $(8.33 \%$ in the first 5 weeks vs $18 \%$ at week $7-12$ vs $25 \%$ thereafter), as it is shown in Table 3.

Table 3

URETERAL STENT ENCRUSTATION, COLORING AND RESISTANCE TO REMOVAL TO INDWELLING TIME

\begin{tabular}{|l|l|l|l|}
\hline Characteristics & $<6$ weeks & $6-12$ weeks & $>12$ weeks \\
\hline No. of stents & 60 & 50 & 24 \\
\hline Encrusted stents & $11(18.33 \%)$ & $28(56 \%)$ & $18(75 \%)$ \\
Moderate encrustation & $8(13.33 \%)$ & $20(40 \%)$ & $11(45.83 \%)$ \\
Severe encrustation & $3(5 \%)$ & $8(10 \%)$ & $7(29.17 \%)$ \\
\hline Color changes & $3(5 \%)$ & $9(18 \%)$ & $8(33.3 \%)$ \\
Minor changes & $2(3.33 \%)$ & $7(14 \%)$ & $6(25 \%)$ \\
Esgential modification & $1(1.67 \%)$ & $2(4 \%)$ & $2(8.3 \%)$ \\
\hline Resistance at the extraction & $5(8.33 \%)$ & $9(18 \%)$ & $6(25 \%)$ \\
Moderate resistance & $4(6.66 \%)$ & $8(16 \%)$ & $4(16.66 \%)$ \\
Irremovable & $1(1.66 \%)$ & $1(2 \%)$ & $2(8.33 \%)$ \\
\hline
\end{tabular}

Fourier Transform Infrared Spectroscopy determined that the most encrustations were mix-compound (64.91\%). Calcium Oxalate Monohydrate (22.81\%) represented the main encrustation in the single-compound group. The proportion of different kind of encrustation was shown on Table 4 . The urinary culture was positive in $24.63 \%$ ( 33 patients).

Finney and Hepperlen used the modern ureteral $\mathrm{J} J$ stents for the first time in 1978. Since then, a lot of materials and coatings have been developed to prevent the complications $[1,11]$. Although there are a lot of factors that influence the 
Table 4

PROPORTION OF DIFFERENT KIND OF ENCRUSTATION

\begin{tabular}{|l|l|l|}
\hline Encrustation compound & No. & Rate (\%) \\
\hline Calcium Oxalate Monohidrat (COM) & 13 & 22.81 \\
\hline Apatite & 1 & 1.75 \\
\hline Uric acid & 3 & 5.27 \\
\hline Struvite & 2 & 3.51 \\
\hline Cystine & 1 & 1.75 \\
\hline Mix & 37 & 64.91 \\
COM+Calcium Oxalate Dihydrate (COD) & 1 & 1.75 \\
COM+hydroxyapatite & 25 & 43.86 \\
COM+uric acid & 4 & 7.03 \\
COM+apatite & 3 & 5.27 \\
COM+struvite & 1 & 1.75 \\
Hydroxyapatite+struvite & 1 & 1.75 \\
Struvite+CO & 1 & 1.75 \\
\hline Others & 1 & 1.75 \\
\hline TOTAL & 57 & 100 \\
\hline
\end{tabular}

occurrence of encrustation such as: lithiasis, urinary sepsis [12], systemic malignancy $[13,14]$, chemotherapy [15], urinary tract malignancy [16], pregnancy $[17,18]$, chronic kidney disease [19] and metabolic abnormalities, the indwelling time remains the primordial factor affecting the rate of encrustation [20-24]. More rare, other comorbidities or treatments may have an influence on the rate of encrustation [25-32].

As mentioned earlier, the indwelling time is the main variable that affects rate of incrustation. El-Faqih and Kawahara indicated that the rate of encrustation on ureteral stents was $9.2-26.8 \%$ in the first 5 weeks, 47.5 $56.9 \%$ between week $6-12$, and $75.9-76$. \% after 12 weeks $[33,34]$. Our article supports the earlier mentioned data: the ureteral stentencrustation on the stents with indwelling time less than 6 weeks was 18.33, 56\% between week 712 and $75 \%$ thereafter. The most encrusted situs was the proximal end or also called the upper curl followed by the distal curl and body (Table 2). Singh el al. reported that the most encrusted situs is the upper curl [35]. The presence of encrustation on the superior part of the stent may have been greater because the inferior part of the stent and the body are affected by a greater peristalsis that washes away the debris [32, 33, 36].

The stent caliber is another import variable that affects the encrustation. The study on encrustation and incrustation has determined that the incrustation precedes encrustation [34], therefore a stent with a greater caliber will allow the urine to flow for a bigger time and will need more time for its lumen to be incrusted therefore the encrustation will appear much latter. El-Fagih and Kawahara have described that a smaller caliber stents have a bigger rate of encrustation than a larger one [33, 34]. Our study supports this data; the smaller caliber had a bigger encrustation rate that is statistically significant.

The mechanism that affects the color of the stent is not fully elucidated; however, there are speculations about these modifications: the stents contain iron (used for their radiopaque) that enters in a chemical reaction with the hydrogen sulfide produced by some bacteria; as a result of the interaction iron sulfide is formed that modifies the stent color [34]. The FT-IR analysis of the encrustations in our study has determined that Calcium Oxalate is the main element of the encrustation and that does not differ from the ureteral and renal lithiasis [37]. As a result, the pathophysiology of ureteral encrustation is very similar to the encrustation of the urinary tract.

\section{Conclusions}

Our study has shown that indwelling time is the main risk factor for encrustation. We cannot suggest the best time when the stent must be extracted/changed and it is mainly case-dependent; however, extraction/change in the first 5 weeks will cause less complication than those that will have a bigger indwelling time. The main compound of the stent encrustation is represented by calcium oxalate that is no different from the reno/ureteral lithiasis so the pathophysiology of the stent encrustation seems to be very similar to that of the urinary lithiasis.

\section{References}

IFINNEY, R., P., J. Urol., 167, nr. 2, p. 1135

2.ZIMSKIND, P.D., FETTER, T.R., WILKERSON, J.L., J. Urol., 97, nr. 5, 1967, p. 840

3.PRICOP, C., Negru, I., CIUTA, C., J inga, V., ILIE'IU, A., CHECHERITA, I.A., Jinga, M., Farmacia, 64, nr. 5, 2016, p. 757

4.PRICOP, C., BRANISTEANU, D., D., ORSOLYA, M., PUIA, D., MATEI, A., CHECHERITA, I.A., Int Urol Nephrol., 48, nr. 2, 2016, p. 183

5.BEIKO, D.T., KNUDSEN, B.E., DENSTEDT, J.D., J. Endourol., 17, nr. 4, 2003, p. 195

6.CHECHERITA, I.A., TURCU, F., DRAGOMIRESCU, R.F., CIOCALTEU, A., Rom. J. Morphol. Embryol., 51, nr. 1, 2010, p. 21

7.CHECHERITA, I.A., SMARANDACHE, D., DAVID, C., CIOCALTEU, A., ION, D., A., LASCAR, I., Rom. J. Morphol. Embryol., 53, nr. 1, 2012, p. 7

8.VENKATESAN, N., SHROFF, S., JEYACHANDRAN K., DOBLE, M., Urol. Res., 39, nr. 1, 2011, p. 29

9.TENKE, P., KOVES, B., NAGY, K., HULTGREN, S.J., MENDLING, W., WULLT, B., GRABE, M., WAGENLEHNER, F.M., CEK, M., PICKARD, R., BOTTO, H., NABER, K.G., BJ ERKLUND JOHANSEN, T.E., World. J. Urol., 30, nr. 1, 2012, p. 51

10.PRICOP, C., SUDITU, N., VRINCEANU, R., PUIA, D., DIMITRIU, D.C., CIUTA, C., TODOSI, L., CHECHERITA, I.A., Nobel Med., 11, nr. 3, 2015, p. 42

11.RADULESCU, M., ANDRONESCU, E., CIRJA, A., HOLBAN, A., M., MOGOANTA, L., BALSEANU, T.A., CATALIN, B., NEAGU, T.P., LASCAR, I., FLOREA, D.A., GRUMEZESCU, A.M., Rom. J. Morphol. Embryol., 57, nr. 1, 2016, p. 107

12.DIACONU, C., BALACEANU, A., MOROSAN, E., Farmacia, 63, nr. 6, 2015, p. 811

13.POIANA, C., NEAMTU, M.C., AVRAMESCU, E.T., CARSOTE, M., TRIFANESCU, R., TERZEA, D., NEAMTU, O.M., FERECHIDE, D., DANCIULESCU, MIULESCU, R., Rom. J. Morphol. Embryol., 54, nr. 3 Suppl, 2013, p. 717

14.PAUN, D., L., POIANA, C., PETRIS, R., RADIAN, S., MIULESCU, R.D., CONSTANTINESCU, G., ORBAN, C., Chirurgia (Bucur.), 108, nr. 6, 2013, p. 900

15.CIUHU, A.N., RAHNEA NITA, R.A., POPESCU, M., DUMITRU BADIU, C.D., PANTEA STOIAN, A.M., LUPULIASA, D., GHERGHICEANU, F., DIACONU, C.C., RAHNEA NITA, G., Farmacia, 65, nr. 2, 2017, p. 173

16.GEAVLETE, B.F., BRINZEA, A., CHECHERITA, I.A., ZURAC, S.A., GEORGESCU, D.A., BASTIAN, A.E., ENE, C.V., BULAI, C.A., GEAVLETE, D.O., ZAHARIA, M.R., GEAVLETE, P.A., Rom. J. Morphol. Embryol., 56, nr. 3, 2015, p. 1069 
17.DIACONU, C., BALACEANU, A., BARTOS, D., Central European Journal of Medicine, 8, nr. 5, 2013, p. 548

18.CAPATINA, C., RADIAN, S., BACIU, I., GHINEA, A., DECIU, D., DUMITRA'CU, A., CIUBOTARU, V., POIANA, C., Acta Endocrinol., 12, nr. 4, 2016

19.CHECHERITA, I.A., DAVID, C., CIOCALTEU, A., LASCAR, I., Chirurgia (Bucur.), 104, nr. 5, 2009, p. 525

20.ABDEL-DAIM, M.M., ZAKHARY, N.I., ALEYA, L., BUNGAU, S.G., BOHARA, R.A., SIDDIQI, N.J ., Oxid. Med. Cell. Longev., 2018, 2018, ID 2098123

21.CAO, X.M., LIU, J.M., LIAO, B.H., ZHU, C.H., LI, H., LUO, D.Y., WANG, J.Z., WANG, K.J., Sichuan Da Xue Xue Bao Yi Xue Ban, 46, nr. 3,2015, p. 431

22.BULTITUDE, M.F., TIPTAFT, R.C., GLASS, J.M., DASGUPTA, P., Urology, 62, nr. 4, 2003, p. 622

23.BUMBU, A., PASCA, B., TIT, D. M., BUNGAU, S., BUMBU, G., Farmacia, 64, nr. 3, 2016, p. 419

24.TIT, D.M., PALLAG, A., IOVAN, C., FURAU, G., FURAU, C., BUNGAU, S., Iran. J. Public Health, 46, nr. 11, 2017, p. 1128

25.PARASCHIV, B., TOMA, C.L., DIACONU, C.C., Archivos de Bronconeumologia, 49, nr. 7, 2013, p. 315

26.DIACONU C., DUMITRU, N., FRUNTELATA, A., LACAU, S., BARTOS,

D., Acta Cardiologica Sinica, 31, nr. 1, 2015, p. 83

27.TIGLIS, M., GRINTESCU, I.C., NEAGU, T.P., TURCU, F.L., COCOLOS,

A.M., GRINESCU, I.M., Rev. Chim. (Bucharest), 69, no. 2, 2018, p. 391
28.NEAGU, T.P., COCOLOS, I., COBILINSCHI, C., TIGLIS, M., FLORESCU, I.P., BADILA, E., SINESCU, R.D., Rev. Chim. (Bucharest), 68, no. 12, 2017, p. 2978

29.COCOLOS, A.M., DUMITRU, N., PETROVA, E.N., COCOLOS, I., TIGLIS, M., DRAGOMIRESCU, R.F.I., OLARU, M., DUMITRU, A., GHEMIGIAN, A., M., Rev. Chim. (Bucharest), 69, no. 1, 2018, p. 134 30.NEAGU, T.P., TIGLIS, M., BOTEZATU, D., ENACHE, V., COBILINSCHI, C.O., VALCEA-PRECUP, M.S., GRINPESCU, I.M., Rom. J. Morphol. Embryol., 58, nr. 1, 2017, p. 33

31.MIREA, D., MIREA, L.E., NITIPIR, C., TIGLIS, M., GRINTESCU, I.C., NEAGU, T.P., MOGOANTA, C., A., GRINTESCU, I., M., Rom. J. Morphol. Embryol., 58, nr. 3, 2017, p. 1077

32.NEAGU, T.P., SINESCU, R.D., ENACHE, V., ACHIM, S.C., TIGLIS, M., MIREA, L.E., Rom. J. Morphol. Embryol., 58, nr. 2, 2017, p. 603

33.EL-FAQIH, S.R., SHAMSUDDIN, A.B., CHAKRABARTI, A., ATASSI, R., KARDAR, A.H., OSMAN, M.K., J. Urol., 146, nr. 6, 1991, p. 1487

34.KAWAHARA, T., ITO, H., TERAO, H., YOSHIDA, M., MATSUZAKI, J., J. Endourol., 26, nr. 2, 2012, p. 178

35.SINGH, I., GUPTA, N.P., HEMAL, A.K., ARON, M., SETH, A., DOGRA, P.N., Urology, 58, nr. 4, 2001, p. 526.

36.BULTITUDE, M.F., TIPTAFT, R.C., GLASS, J.M., DASGUPTA, P., Urology, 62, nr. 3, 2003, p. 622

37.ZHANG, M., ZHANG, X., ZHANG B., WANG, D., Microsc. Res. Tech., 79, nr. 11, 2016 p. 1038

Manuscript received: 15.08 .2018 